\title{
Abstract \\ The Effect of pH and Fly Ash on the Electrochemical Performance of Stainless-Steel Concrete Reinforcement in Harsh Environments ${ }^{\dagger}$
}

\author{
Sofia Tsouli ${ }^{1}$, Christos Nikolaidis ${ }^{1}$, Spyridon Kleftakis ${ }^{1}$ and Angeliki G. Lekatou ${ }^{1,2, *(D)}$ \\ 1 Laboratory of Applied Metallurgy, Department of Materials Science and Engineering, School of Engineering, \\ University of Ioannina, 45110 Ioannina, Greece; stsouli@uoi.gr (S.T.); chrisnikolaid@hotmail.com (C.N.); \\ skleftak@uoi.gr (S.K.) \\ 2 Institute of Materials Science and Computing, University Research Center of Ioannina (URCI), \\ 45110 Ioannina, Greece \\ * Correspondence: alekatou@uoi.gr; Tel.: +30-26510-07309 \\ + Presented at the First Corrosion and Materials Degradation Web Conference, 17-19 May 2021; Available \\ online: https://cmdwc2021.sciforum.net/.
}

Citation: Tsouli, S.; Nikolaidis, C.; Kleftakis, S.; Lekatou, A.G. The Effect of $\mathrm{pH}$ and Fly Ash on the Electrochemical Performance of Stainless-Steel Concrete Reinforcement in Harsh Environments. Mater. Proc. 2021, 6, 25. https://doi.org/10.3390/ CMDWC2021-09976

Academic Editor: David M

Bastidas

Published: 8 May 2021

Publisher's Note: MDPI stays neutral with regard to jurisdictional claims in published maps and institutional affiliations.

Copyright: (C) 2021 by the authors. Licensee MDPI, Basel, Switzerland. This article is an open access article distributed under the terms and conditions of the Creative Commons Attribution (CC BY) license (https:// creativecommons.org/licenses/by/ $4.0 /)$.

\begin{abstract}
The corrosion of steel reinforcement is the most significant factor responsible for the premature deterioration of the durability and seismic resistance of reinforced concrete structures. As such, the main objective of the present study is the investigation of the effect of fly ash (FA) as a corrosion inhibitor and $\mathrm{pH}$ on the electrochemical behavior of $316 \mathrm{~L}$ and $304 \mathrm{~L}$ concrete reinforcement in a simulating concrete pore solution exposed to aggressive environments, i.e., acid rain. The corrosion performance of 316 L and 304L stainless steel rebars was examined by means of cyclic (reverse) polarization in order to evaluate the susceptibility of the rebars to localized corrosion. Two types of electrolyte were used. The first electrolyte was a highly alkaline solution simulating fresh concrete exposed to acid rain $(\mathrm{pH} \approx 12$ ), while the second electrolyte was a mildly alkaline solution simulating corroded concrete cover that exposed the reinforcement to direct acid rain attack $(\mathrm{pH} \approx 8)$. Both solutions contained $\mathrm{Ca}(\mathrm{OH})_{2}$, an acid-rain-simulating solution, and FA (replacing 0-25 wt.\% of $\left.\mathrm{Ca}(\mathrm{OH})_{2}\right)$ as a corrosion inhibitor. In both electrolytes, the beneficial effect of FA replacing up to $20 \mathrm{wt} . \%$ of $\mathrm{Ca}(\mathrm{OH})_{2}$ on the corrosion resistance of both $316 \mathrm{~L}$ and $304 \mathrm{~L}$ rebars was manifested. However, this trend was reversed at the $25 \mathrm{wt} . \%$ replacement of $\mathrm{Ca}(\mathrm{OH})_{2}$ due to the localized presence of agglomerates of FA on the surface of the steel. The above finding was confirmed by SEM/EDX examination of cross-sections after cyclic polarization. An important conclusion of this study was the feasibility of replacing $316 \mathrm{~L}$ stainless steel with $304 \mathrm{~L}$ (at $\mathrm{pH} \approx 12$ ) in critical applications, such as the restoration of ancient monuments, provided that FA is included in the concrete mixture, even at low contents (10 or $15 \mathrm{wt} . \%$ of cement).
\end{abstract}

Keywords: AISI 316L rebars; AISI 304L rebars; fly ash; acid rain; cyclic potentiodynamic polarization

Supplementary Materials: The conference presentation file is available at https:/ /www.mdpi.com/ article/10.3390/CMDWC2021-09976/s1.

Funding: This research received no external funding.

Institutional Review Board Statement: Not applicable.

Informed Consent Statement: Not applicable.

Data Availability Statement: Not applicable.

Conflicts of Interest: The authors declare no conflict of interest. 